\title{
Gorazd: Portal digital al limbii slave vechi și studiile slavo-române
}

\author{
Vladislav Knoll ${ }^{\oplus \Delta \star}$ \\ Institutul de Studii Slave, Academia de Științe a Republicii Cehe, Valentinská 1, 11000 Praga, Republica Cehă
}

\author{
Despre articol \\ Istoric: \\ Primit 13 septembrie 2021 \\ Acceptat 5 octombrie 2021 \\ Publicat 12 decembrie 2021 \\ Cuvinte-cheie: \\ slava veche \\ slavona românească \\ lexicografie digitală \\ lexicografie istorică \\ română veche \\ împrumuturi din slavonă
}

\begin{abstract}
Rezumat
Obiectivul studiului de față este de a prezenta utilitatea proiectului Gorazd: An Old Church Digital Hub pentru cercetătorii care lucrează cu texte românești vechi și cu texte slavone scrise pe teritoriul României de astăzi. Proiectul Gorazd a fost realizat în perioada 2016-2020 și include o cartotecă pentru limba slavă veche și trei baze de date lexicale de texte în slava veche, dintre care cea mai extinsă este reprezentată de versiunea digitalizată și actualizată a monumentalei lucrări Lexicon lingux paleoslovenice (vol. I-IV, 1958-1997) elaborată de către Institutul de Studii Slave al Academiei de Științe din Republica Cehă. Datorită faptului că Proiectul Gorazd utilizează limba engleză ca metalimbaj, aria sa de aplicare nu este limitată la filologii specializați pe slavistică, ci rămîne deschisă și cercetătorilor din domenii înrudite. Dicționarele din cadrul Gorazd Digital Hub pot servi ca instrument de referință nu numai pentru vocabularul slavonic cu cele mai vechi atestări și semantica acestuia, ci și pentru concordanțele biblice ale celei mai vechi redacții a Bibliei slavone și cele mai vechi forme morfologice atestate ale slavei vechi.
\end{abstract}

\section{Introducere: informaţii de bază despre Gorazd}

Gorazd: An Old Church Slavonic Digital Hub (gorazd.org) este un proiect din cadrul programului NAKI II al Ministerului de Cultură al Republicii Cehe desfășurat în perioada 2016-2020 la Institutul de Studii Slave al Academiei de Științe din Cehia. După cum sugerează și numele proiectului, principalul său obiectiv a fost acela de a aduna vocabularul limbii slave vechi (la care ne vom referi în continuare ca SV). Sv poate fi considerată prima etapă din dezvoltarea slavonei bisericești (cf. Mathiesen, 1984, p. 46-47; Tolstoj, 1988, p. 47; Mareš, 2000, p. 542-543), care a jucat un rol important ca limbă clasică supra-confesională în Europa Centrală, de Est și de Sud-Est și a cărei funcție constantă a fost cea liturgică. Datorită acestui fapt și selecției specifice a textelor-sursă, Gorazd Digital Hub poate servi ca instrument valid pentru cercetătorii și studenții care se ocupă de texte românești vechi sau de texte slavone apărute pe teritoriul României de astăzi. Înainte de a descrie maniera în care Gorazd poate fi utilizat în acest scop, vom face o scurtă caracterizare a conținutului Gorazd și a instrumentelor și bazelor de date pe care acesta le oferă. Nu vom furniza însă prea multe detalii referitoare la istoria și contextul Proiectului Gorazd, deoarece acestea sînt disponibile în alte surse, atît în limba română, cît și în limba engleză (Pilát et al., 2018; Knoll, 2019a,b).

Proiectul Gorazd a furnizat două tipuri de rezultate: lexicografice și de software. Partea lexicografică a proiectului a cuprins digitalizarea a trei dicționare de slavonă și a unui catalog de fișe de slavonă create de trei generații de cercetători membri ai Institutului de Studii Slave. Catalogul de fișe de slavonă bisericească veche se bazează pe cea mai extinsă dintre cele patru cartoteci interdependente, a cărei elaborare a început încă din 1943. Versiunea digitalizată a acestuia include 712813 de fișe care acoperă toate formele atestate în textele extrase. Forma standardizată a fișelor a servit drept model pentru crearea unor proiecte similare. Cel mai extins dintre dicționare, Old Church Slavonic Dictionary (ocsD) [Dicționar de Slavă Veche], este o versiune digitalizată a Lexicon lingux paleslovenica (LLP) publicat între 1958 și 1997 în 52 de fascicule și 4 volume cu Suplimente încorporate în Volumul I (Addenda), versiune a cărei elaborare a început în 2008.

*Adresă de corespondență: knoll@slu.cas.cz. 
Astfel, versiunea digitalizată a lemelor care încep cu literele $\mathbf{a}-\mathbf{n}$ a fost complet revizuită, fiind adăugate noi extrase de text. În afara de volumul I, complet revizuit, versiunea digitală OCSD diferă de LLP original și din perspectiva metalimbajului. În timp ce în LLP este folosită limba latină, în OCSD toate explicaţiile de natură lingvistică și factuală sînt furnizate în limba engleză. Engleza a devenit și una din limbile pentru echivalente, alături de germană, rusă, cehă, latină și respectiv greaca și germana înaltă veche (limbi ale textelor model), care erau deja incluse în LLP. În prezent, OCSD conține 18944 de intrări.

A doua lucrare lexicografică inclusă este Dictionary of the Oldest Old Church Slavonic Manuscripts (Doocsm) [Dicționarul celor mai vechi manuscrise al limbii slave vechi], care conține 11563 de intrări. Acesta reprezintă o versiune revăzută și extinsă a Staroslavjanskij slovar' (po rukopisjam X-XI vekov), publicată inițial la Moscova în 1994, rodul colaborării între cercetătorii ruși și cei cehi. Cea de-a treia și cea mai recentă bază de date lexicografică este Greek-ocs Index [Indexul grec-slav vechi], care conține pînă în prezent 2542 de intrări. Acesta reprezintă primul volum (IVGP, literele $\alpha-\gamma$, elaborat în perioada 2004-2014) al unui instrument care se adresează criticilor de text și specialiștilor în traductologie, și chiar cercetătorilor specializați în studii teologice.

Cea de-a doua parte a proiectului, la fel de importantă, a fost cea legată de software. Această parte a avut două obiective principale: (a) crearea de instrumente pentru digitalizarea dicționarelor istorice multilingve (multi-script); (b) crearea unei/unor interfețe de prezentare pentru lucrările lexicografice.

Referitor la primul obiectiv, a fost vizată propunerea unui tip de software care să automatizeze la maximum procesul de digitalizare și să permită corectarea facilă sau realizarea unui dicționar digital de către un utilizator cu cunoștințe minime de IT. Au rezultat astfel trei instrumente care în prezent sînt disponibile gratuit pe website-ul nostru.

Gorazd Generator permite generarea automată de intrări de dicționar pe baza OCR (recunoașterea optică a caracterelor) (ALTO/XML) sau a fișierelor $\mathrm{TXT}^{1}$. În cadrul proiectului, recunoașterea optică a fost realizată cu Serverul de Recunoaștere ABBYY. Sistemele de scriere recunoscute au fost latin (cehă, germană, latină, germana veche înaltă), sistemul grecesc politonic, scrierea chirilică civilă (rusa modernă) și scrierea chirilică veche (uncială) (pentru sv). Pentru rezultate optime în recunoașterea sv, a fost creat Dictionary for Old Church Slavonic Optical Character Recognition [Dicționar pentru Recunoașterea Optică a Caracterelor Slavei Vechi]. În plus, acest instrument este în prezent disponibil pentru toate persoanele interesate $^{2}$. Pe baza unor criterii predefinite, Gorazd Generator desparte textele în intrări de dicționar și stabilește structura XML de bază a intrării respective.

Gorazd Editor permite corectarea și editarea rezultatelor procesului OCR (recunoașterea optică a caracterelor) de către utilizatori care nu au cunoștințe de XML. Acest instrument se bazează pe programul open source INVENIO ${ }^{3}$ și permite compararea facilă a copiei scanate a lucrării lexicografice cu rezultatul furnizat de Gorazd Generator. Actualizarea structurii XML se realizează intuitiv prin utilizarea culorilor și a combinațiilor pe tastatură. Noul conținut care rezultă este la fel de ușor de utilizat ca și MS Word ${ }^{4}$.

Ultimul din aceste instrumente este Gorazd Export, care permite pregătirea pentru imprimare a întregii baze de date elaborate de aplicaţiile menționate anterior. Acest instrument permite generarea unui fişier în format HTML, DOC sau $\mathrm{RTF}^{5}$. Acest set de programe este astfel, cu siguranţă, potrivit pentru procesarea lucrărilor lexicografice sau enciclopedice în limba română veche sau slavona romînească, respectiv a lucrărilor care combină alfabetele latin, chirilic și grecesc.

$\mathrm{Al}$ doilea set de instrumente software dezvoltat în cadrul Proiectului Gorazd este reprezentat de interfețele de prezentare. Interfața denumită Gulliver ${ }^{6}$ include cele trei dicționare menționate care pot fi accesate prin utilizarea de instrumente avansate de căutare, pentru care sînt disponibile tastatura virtuală

\footnotetext{
${ }^{1}$ Detalii suplimentare și pachetul de instalare sînt disponibile la gorazd.org.

${ }^{2}$ Instrumentul cu informații suplimentare și manualul utilizatorului sînt disponibile la gorazd.org.

${ }^{3}$ Dezvoltat de CERN (Organizația Europeană pentru Cercetări Nucleare); cf. inveniosoftware.org.

${ }^{4}$ Detalii suplimentare și pachetul de instalare sînt disponibile la gorazd.org.

${ }^{5}$ Detalii suplimentare și pachetul de instalare sînt disponibile la gorazd.org.

${ }^{6}$ Acces direct la gorazd.org.
} 
și suportul de căutare. Utilizatorul poate căuta lexeme Sv și, mai mult, dicționarul permite căutarea echivalenţilor Svîn limbi moderne (engleză, germană, rusă, cehă) sau clasice (latină, greacă). De asemenea, utilizatorul poate predefini criterii de căutare specifice, cum ar fi categorii gramaticale sau grup de texte. Rezultatele căutării pot fi utilizate în scop statistic, permiţînd de exemplu generarea unei liste complete de lexeme care aparțin unei anumite declinări în unul sau mai multe texte SV anume. OCSD și Greekocs Index sînt inter-relaționate. OcsD este legat și de Cartoteca slavă veche (Old Church Slavonic Card Index). În acest mod, fiecare intrare OCSD permite consultarea tuturor formelor atestate ale unei unități lexicale anume. În afară de accesul direct prin intermediul interfeței Gulliver, cartoteca poate fi consultată cu ușurință într-o interfață separată, Archive of Old Church Slavonic Card Index [Arhiva Cartotecii sv], care permite răsfoirea virtuală a întregului catalog de fișe ${ }^{7}$.

Cercetătorii care lucrează cu texte sau materiale lingvistice în slava veche sau slavona bisericească au la dispoziție și o serie de instrumente suplimentare, precum:

- convertorul de numerale chirilice și glagolitice ${ }^{8}$,

- o listă online cu legături către colecții digitale de manuscrise și ediții timpurii în slavona bisericească9,

- o listă online cu legături către dicționare de limbile slave istorice digitalizate sau concepute în format digital (care acoperă în principal varietăți din perioada medievală și începutul epocii moderne) ${ }^{10}$.

Ultimele două instrumente includ și sursele legate de teritoriile în care se vorbește limba română. Toate rezultatele și bazele de date menționate sînt accesibile de pe pagina web (gorazd.org), pe care se poate opta, la fel ca și în cazul interfețelor, pentru trei versiuni de limbă, perfect echivalente: engleză, rusă și cehă. Un produs adițional al Proiectului Gorazd este pagina de Facebook a proiectului (facebook.com), în care se regăsesc materiale de popularizare pentru cercetări legate de slava veche și slavona bisericească, filologie slavă și studiul limbilor vechi, în general.

\section{Ortografie}

În a doua parte a studiului nostru vom prezenta Gorazd ca instrument pentru cercetătorii care studiază texte românești vechi sau slavone în România de astăzi. Aceasta va constitui una din perspectivele din care vom explica conținutul Gorazd Digital Hub. La utilizarea bazelor de date, este important ca utilizatorul să înțeleagă că există diferențe între baza noastră de date și textul examinat. Norma de ortografiere utilizată de OCSD corespunde în general normei utilizate de manualele și dicționarele de slavă veche. Cu toate acestea, există anumite elemente specifice care trebuie discutate în detaliu, mai exact prin comparație cu alte surse utilizate în mod obișnuit ${ }^{11}$ :

\begin{tabular}{l|l|l|l|l} 
Slavă comună $^{12}$ sau greacă & OCSD & SBR $^{13}$ & $\begin{array}{l}\text { Miklosich } \\
(\mathbf{1 8 6 2 - 1 8 6 5})^{14}\end{array}$ & $\begin{array}{l}\text { Olteanu } \text { et al. } \\
(\mathbf{1 9 7 5})^{15}\end{array}$ \\
\hline *(j)aviti a apărea' & Авити & Іавити & Іавити & гвити
\end{tabular}

\footnotetext{
${ }^{7}$ Acces direct la gorazd.org.

${ }^{8}$ Acces direct la prevodnik.gorazd.org.

${ }^{9}$ Acces direct la gorazd.org.

${ }^{10}$ Acces direct la gorazd.org.

${ }^{11}$ Norma ortografică OCSD este explicată în LLP 1, LIII-LV (online, pînă în prezent în latină).

${ }^{12}$ Pe baza înlocuirilor, în ESJs: $\mathbf{~} \mathbf{~}>\check{c}$ și $\mathbf{~} \mathbf{z}>\check{u}$.

${ }^{13}$ SBR este disponibil online în cadrul bazei de date lexicografice HistDict (histdict.uni-sofia.bg). Ortografia acestuia servește drept normă pentru următoarele dicționare incluse în HistDict. Această bază de date se ocupă, de asemenea, de sursele slavonei bisericești medii, ceea ce îl face să fie un instrument de maximă importanţă pentru studiul textelor slavone din România.

${ }^{14}$ Poate fi consultat online pe monumentaserbica.branatomic.com. Este considerat în mod tradițional cel mai popular dicționar de slavonă bisericească (datorită faptului că e disponibil) din România și include, de asemenea, și o serie de texte slavone din România (inscripțiile de la Argeș). Cu toate acestea, îi lipsește o bază bine definită pentru extragerea fragmentelor și în consecință ar trebui utilizat cu precauție.

${ }^{15}$ Cel mai bun manual de slavă veche disponibil în limba română (și unul dintre cele mai bune manuale de sv în general), cu o perspectivă detaliată asupra trăsăturilor lingvistice ale varietăților de slavonă utilizate în România și care constituie un punct de referință petru lucrările ulterioare.
} 


\begin{tabular}{|c|c|c|c|c|}
\hline *(j)eterü 'cineva' & ETEЕऽҚ & ЮТЕ९Қ & ЮТЕ९Қ & ЮТЕ९Қ \\
\hline *dzélo 'foarte' & StkAo & $3 \mathrm{k} / 0$ & $3 \mathrm{k} / 0$ & stho \\
\hline *bol'ii 'mai mare' & Боภิни & 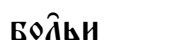 & Болий & БОАни \\
\hline *kon'ǐ'cal' & KоN̂́ & KON̂ b & KONh & KON'b \\
\hline *rybar'î'pescar' & & & 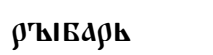 & \\
\hline *žrirtva jertfă' & 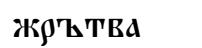 & ж$\rho \mathbf{L T B d}$ & 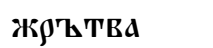 & ж$\rho \mathbf{L T B d}$ \\
\hline *tǔlkq 'eu bat' & тиһкж & ТАькж & тиҺкж & ТАҚкж \\
\hline *krǐstijanǔ 'creștin' & көцстнанақ & көцстнганқ & 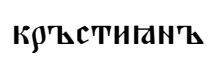 & коқстіанқ \\
\hline *slǐza 'lacrimă' & cAb3d & cAb3d & cAth3d & cAь3А (cАh3А \\
\hline 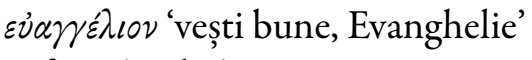 & ЕВАКГ̂ЕАНЮ & ЕВаNГ̂ЕАLЮ & ЮвАNГЕАИЮ & ЮВАNГЕАНЮ \\
\hline$\psi \alpha \lambda \mu o ́ s$ 'psalm' & ПсАА'ҚА'Қ & ПсААҚАһ & ४ал'ъдты & 0 \\
\hline
\end{tabular}

În ansamblu, OCSD furnizează o concordanță ușor diferită între etimologie și formele păstrate în manuscrisele canonice Sv față de alte manuale. În orice caz, suportul de căutare ajută utilizatorul să găsească cuvîntul dorit chiar dacă acesta nu cunoaște cu precizie norma de ortografie, avînd în vedere că fiecare intrare conține și variantele ortografice din textele extrase. Trebuie să adăugăm faptul că există foarte puține diferențe între OCSD și DOOCSM, ceea ce indică un tratament similar al grupurilor consoană lichidă

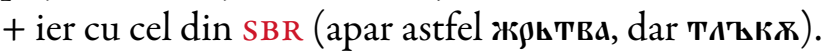

Ortografia limbii slave vechi diferă în mod semnificativ de cea cu care lucrează cărturarul slavo-român. Textele cărturești ale slavonismului cultural propriu-zis (secolul XIV-începutul secolului al XVIII-lea) ${ }^{16}$ au fost scrise în varietăţi ale slavonei bisericești medii, iar din a doua jumătate a secolului al XVII-lea și într-o varietate timpurie a slavonei bisericești noi ${ }^{17}$. Varietatea de slavonă bisericească medie cea mai utilizată pe teritoriile în care se vorbea limba română a fost norma tîrnoveană, cea mai conservatoare dintre varietăţile de slavonă bisericească medie, care a furnizat și baza ortografiei pentru scrierile românești vechi. Mai mult, norma resaviană a fost utilizată și în Țara Românească. Numeroasele variante de ortografie întîlnite în textele din Țara Românească, Moldova și Transilvania se datorează bazelor diferite ale limbilor cancelariilor locale care au intrat în contact cu diverse pronunții liturgice. Redăm mai jos un scurt exemplu de astfel de analiză comparativă:

\begin{tabular}{|c|c|c|c|c|c|}
\hline sv & $\begin{array}{l}\text { Slavona tîr- } \\
\text { noveanáa }^{18}\end{array}$ & $\begin{array}{l}\text { Slavona } \\
\text { resaviană }\end{array}$ & $\begin{array}{l}\text { Cancelaria } \\
\text { din Țara Ro- } \\
\text { mânească }^{19}\end{array}$ & $\begin{array}{l}\text { Cancelaria } \\
\text { din } \\
\text { Moldova }^{20}\end{array}$ & $\begin{array}{l}\text { Slavona nouă } \\
\text { timpurie }^{21}\end{array}$ \\
\hline $\begin{array}{l}\text { Тьдьница } \\
\text { 'temniță' }\end{array}$ & ТЕАНИЦА & тьдница & $\begin{array}{l}\text { ТЬАница/ } \\
\text { ТЕдницА } \\
\text { (ТАдница) } \\
\end{array}$ & \multicolumn{2}{|c|}{ ТЕАКИЦА } \\
\hline BLCE 'toţi' & B'ZCE & В'ИCE/вЬCE & В'ИCE/ВЬCE/CВE & В'ИCE/OYCE & ВСЕ/В'ИCE/ВЬCE \\
\hline $\begin{array}{l}\text { нкка } \\
\text { 'suferință }\end{array}$ & Нжка & ноүка & $\mathrm{H} 8 \mathrm{Ka} / \mathrm{H}$ & ка/нхка & ноүка (нжка) \\
\hline
\end{tabular}

\footnotetext{
${ }^{16}$ Poate fi definit ca perioada dintre înființarea Țărilor Române și etapa finală de înlocuire a slavonei bisericești de către română ca limbă liturgică.

${ }^{17}$ Mai ales în Țara Românească, unde, începînd din 1635, tipăriturile nu mai apăreau în slavona bisericească (cu excepția Penticostarului de la 1649) și cu rezerva că ortografia din Molitfelnicul de la 1635 a avut un caracter tranzitoriu. În Moldova, tranziția către noua slavonă bisericească a fost mai lentă, deoarece la acea vreme și varietate locală de slavonă bisericească medie și limba română dețineau poziții puternice.

${ }^{18}$ Conform dicționarului din cadrul ediției Bogdan (1922) a Cronicii lui Constantin Manasses, care servește uneori drept dicționar al slavonei bisericești utilizate în România.

${ }^{19}$ Cf. Djamo-Diaconiță (1971, p. 21-91). XV.

${ }^{20}$ Cf. variația în SSUM, care reprezintă, de fapt, un dicționar al documentelor cancelariei moldovenești din secolele XIV-

${ }^{21}$ Cf. variația din Berynda (1627).
} 


\begin{tabular}{|c|c|c|c|c|c|}
\hline $\begin{array}{l}\text { паннАть } \\
\text { 'amintire' }\end{array}$ & ПанАтТ & ПАHETL & 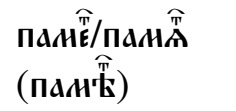 & 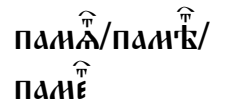 & ПанАть \\
\hline $\begin{array}{l}\text { ААз'ык'ы } \\
\text { 'limbă' }\end{array}$ & $\begin{array}{l}\text { АзыКь } \\
\text { (жзыкь) }\end{array}$ & Єзыки & 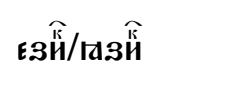 & \multicolumn{2}{|c|}{ 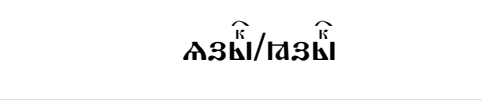 } \\
\hline $\begin{array}{l}\text { ЖАжад } \\
\text { 'sete' }\end{array}$ & жжжАd & ЖЕжАd & $\begin{array}{l}\text { ЖЕжАd } \\
(\text { Ж'ъжАА }\end{array}$ & \multicolumn{2}{|c|}{ ЖажАd/жАжАd } \\
\hline $\begin{array}{l}\text { BOAla } \\
\text { 'voință' }\end{array}$ & BOA' & волtа & $\mathrm{BOAT/BOAE}$ & \multicolumn{2}{|c|}{ BOAA } \\
\hline 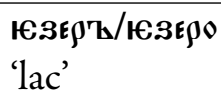 & EZESO & 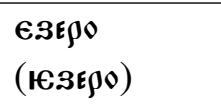 & $\operatorname{ESE} \rho(0)$ & $W 3 E \rho \odot / \epsilon 3 E \rho(\diamond)$ & $\in 3 E \rho 0$ \\
\hline $\begin{array}{l}\text { АоБҺыти '́ } \\
\text { ajunge' }\end{array}$ & \multicolumn{2}{|c|}{ АоБытти 'a ajunge, a dobîndi’ } & $\begin{array}{l}\text { АоБитии 'a } \\
\text { ajunge' }\end{array}$ & $\begin{array}{l}\text { АоБытти } \\
\text { (АоБити) 'а } \\
\text { ajunge, a } \\
\text { dobîndi' }\end{array}$ & АОБь'ти \\
\hline $\mathrm{A}^{\mathrm{T} \mathbf{\mathrm { K }} \mathrm{\prime} \mathbf{\mathrm { s }} \text { parte }}$ & $\mathrm{A} \mathrm{t} \mathrm{k} \mathrm{h}$ & $\mathrm{A} \mathbf{\mathrm { k }} \boldsymbol{\mathrm { s }}$ & 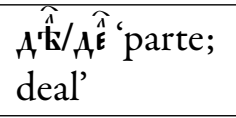 & $\begin{array}{l}A \hat{\hat{n}} / A \hat{\hat{k}} / A \hat{A} / A \hat{\hat{n}} \\
\text { 'deal' }\end{array}$ & A'EA's 'parte' \\
\hline 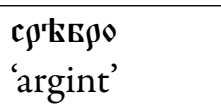 & $\mathfrak{c} \rho \hbar \bar{\hbar} \rho \mathcal{O}$ & 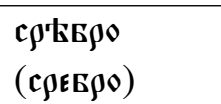 & 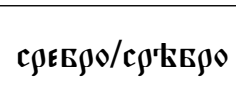 & $\mathfrak{c} \rho \in \overline{\mathrm{B}} \rho \mathcal{O} / \mathfrak{c} \in \rho \in \mathrm{E} \rho \mathcal{O}$ & $\mathfrak{c} \rho \in \mathrm{E} \rho \mathcal{O}$ \\
\hline 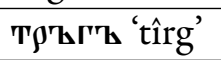 & 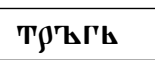 & \multicolumn{2}{|c|}{ 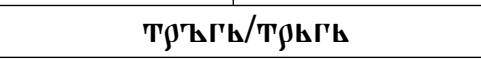 } & \multicolumn{2}{|c|}{ 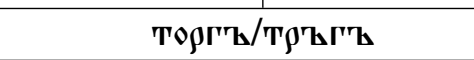 } \\
\hline в $\rho \mathbf{z} \times \mathbf{X}^{\prime \mathbf{z}}$ 'deal' & в $\rho^{\prime} \mathbf{z} X^{\prime \mathbf{b}}$ & \multicolumn{2}{|c|}{$\mathbf{8} \rho \mathbf{k} X_{\mathbf{k}} / \mathbf{B} \rho \mathbf{k} X_{\mathbf{k}}$} & \multicolumn{2}{|c|}{ в $\rho \mathbf{k} X \mathbf{b} /$ ВE$\rho X ' \mathbf{b}$} \\
\hline
\end{tabular}

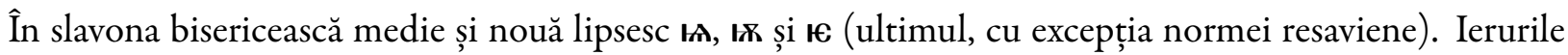
în poziție slabe sînt omise cel mai des (cu excepția unor granițe morfologice și poziții finale), ierurile în poziții puternice sînt adesea supuse vocalizărilor, în timp ce calitatea lor depinde mai degrabă de poziția în cadrul unităţii accentuate sau sînt aleatorii. Pozițiile pentru ${ }^{*},{ }^{*} Q,{ }^{*} e,{ }^{*} j a$ și ${ }^{*} y$ sînt cele mai variabile, fiind dependente de diverse tradiții de ortografiere și pronunție. Atunci cînd comparăm vocabularul textelor românești vechi ${ }^{22}$ cu Sv, trebuie luate în considerare și exemplele cu ocurența următoarelor caracteristici:

- tratamentul ierurilor corespunde normei slavone tîrnovene, e.g. $29^{\mathrm{v}}$ тємнйцд - SV тьдьница 'tem-

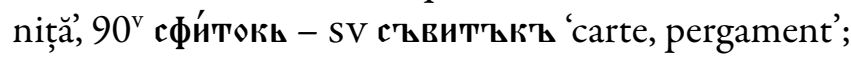

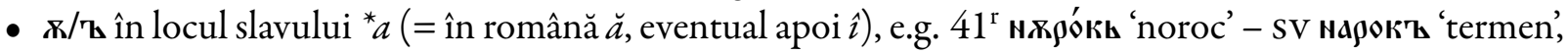

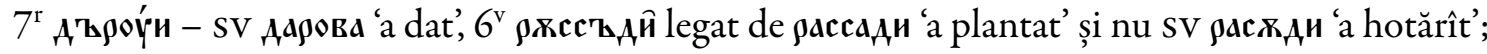

- 't în locul slavului * (= în română ea sau un rezultat al variației t'/

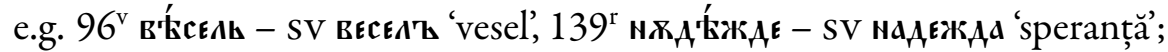

- variaţia o(w)-/oy- la începutul cuvîntului, e.g. $42^{\mathrm{r}}$ '̈

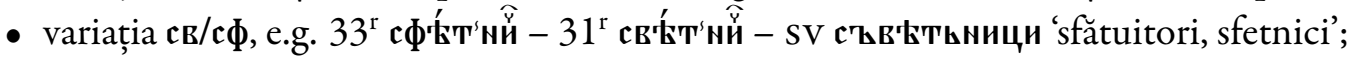

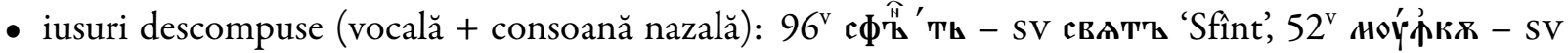
мкка 'suferință’;

- adaptări suplimentare, mai ales în cazul împrumuturilor timpurii (din limbile slave vernaculare), e.g.

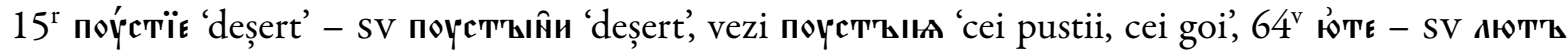
'violent'.

\section{Gorazd ca punct de referință pentru textele în română veche și slavonă din România}

În acest capitol vom menționa cîteva exemple de utilizare a Gorazd Digital Hub ca punct de referință pentru studiile de română veche, respectiv de slavona românească. Fără îndoială, Gorazd este cel mai adesea utilizat pentru consultarea vocabularului. În această privință, trebuie să definim baza de extragere a

\footnotetext{
${ }^{22}$ Exemplele sînt luate din Moxa (1620).
} 
fragmentelor în OCSD și consecințele acesteia pentru cercetătorii de specializați în studii de slavo-română. OCSD cuprinde trei tipuri de texte:

- Manuscrise canonice sv (i.e. cele scrise între secolele al IX-lea și al XI-lea).

- Manuscrise postcanonice, i.e. copii tîrzii în slavona bisericească (inclusiv cele glagolitice croate) ale textelor despre care se presupune că au origine chirilo-metodiană.

- Texte cehe în slavona bisericească, i.e. acele texte despre care se crede că au fost scrise pe teritoriul Cehiei de astăzi în secolele al X-lea și al XI-lea.

Gorazd Digital Hub permite limitarea căutării la doar unul dintre aceste grupuri de texte, la toate sau la doar unul dintre texte. Fiecare intrare include lista textelor care conțin unitatea lexicală în cauză. Această listă ajută la stabilirea grupului de texte de care aparține respectivul lexem. Aproape toate intrările furnizează și o listă de sinonime.

Vocabularul textelor canonice în SV este cel împărtăşit în mare măsură cu SBR și care este și mai complet înregistrat în Doocsm (datorită includerii textelor canonice descoperite mai tîrziu). Din perspectiva filologiei românești merită să amintim că baza dialectală a slavonei bisericești este similară cu cea a dialectului limbii slave comune care se afla în contact cu româna comună. Astfel, această parte a dicționarului conține unități lexicale al căror statut fonologic corespunde cu cel păstrat în limba română, e.g. peșteră

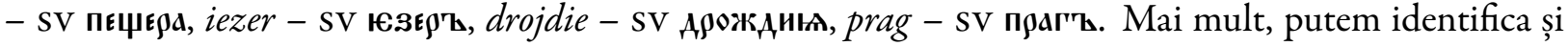

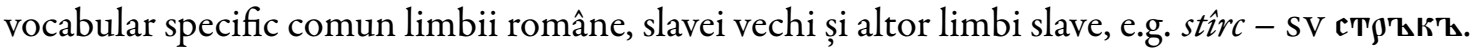

Datorită includerii celui de-al doilea grup de texte, OCSD poate fi folosit ca un fel de concordanță biblică. Cărțile în slavona bisericească care au fost selectate includ Noul Testament, Psalmii, precum și părți ale Vechiului Testament, care conțin Cartea Profeților sau Lecționarul Vechiului Testament (părțile cele mai complete sînt extrase din Geneză, Exod, Cartea Cronicilor și Isaia) și cărțile celor 12 profeți. Este evident că redacția atestată în slavona bisericească medie și tradusă în româna veche nu corespunde în întregime redacției din OCSD, care ar trebui să reprezinte prima redacție, cea chirilo-metodiană. Totuşi, diferența este destul de nesemnificativă și astfel Gorazd Digital Hub rămîne un instrument util pentru cercetătorii care lucrează cu texte biblice în slavona bisericească medie. Acest aspect poate fi ilustrat prin comparația cu împrumuturile slave din Tetraevanghelul lui Coresi (1561) cu lexemele atestate poziționate în același loc în OCSD, e.g.

- $M t, 6,28: 11^{\mathrm{v}}$ кои́н8ль - sv көнн'ъ 'crin',

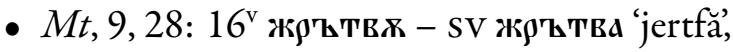

- $M t, 12,31: 24^{\mathrm{v}}$ Xoy 1 - sv Xoyad 'hulă,

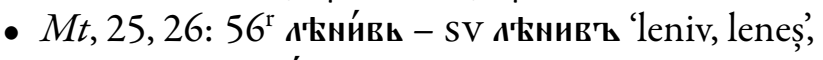

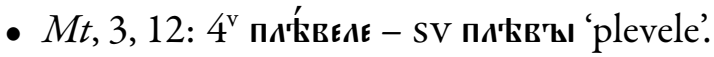

Gorazd Digital Hub permite limitarea căutării doar la cărțile biblice.

$\mathrm{Al}$ treilea grup de texte are mai puțin în comun cu mediul românesc. În orice caz, există unități lexicale, parțial comune cu mediul slav estic, care corespund unor cuvinte românești vechi, respectiv unor cuvinte identificate în textele slavone din România, e.g.: sfită - Czech сs свита 'îmbrăcăminte', dedină - Czech CS A'tănнa 'pămînt moștenit' (la fel și în slavona din Țara Românească, 1456, DRH B 1, p. 196).

În ansamblu, OCSD servește ca prim punct de referință pentru vocabularul textelor religioase în slavona bisericească păstrate în România. Căutarea unui lexem în OCSD permite stabilirea substratului lexical celui mai vechi al unității lexicale investigate și în final legarea acesteia la textul biblic (altfel spus, corpusul model al vocabularului slavonei bisericești). Pentru investigații suplimentare asupra textelor slavone din textele în română sau româna veche recomandăm utilizarea unor instrumente lexicografice suplimentare (vezi Knoll, 2021).

Textele extrase în OCSD conțin și unităţi lexicale tipice pentru textele slavone scrise de autori români sau care sînt atestate în limba română (veche), dar au o semnificaţie diferită. Aceste lexeme pot fi clasificate în două grupe principale: 
- Alte lexeme care corespund împrumuturilor în limba română (veche), e.g. SV ключарь 'chelar' româna veche/slavona românească clucer 'oficial de la curte însărcinat cu aprovizionarea curții și administrarea rezervelor de hrană' (Bolocan et al., 1981, p. 18), sv cnd®dał' 'gardă' - româna veche/slavona românească spatăr 'comandant de cavalerie' (p. 219), sv конис's 'prefect al unei provincii' - româna veche/slavona românească comis 'oficial de la curte însărcinat cu administrarea grajdurilor şi a cailor' (p. 52), sv отьчина 'patrie' - româna veche/slavona românească ocină 'patrimoniu, moștenire' (p. 161).

- Further lexemes corresponding to the borrowings in (Old) Romanian, e.g. sv кмопот'ъ 'vuiet, huruit'

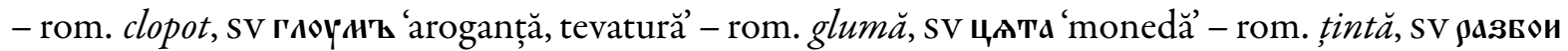

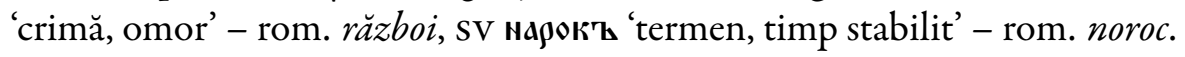

\section{Gorazd ca punct de referință pentru morfologie}

Pe lîngă vocabular, Gorazd poate fi utilizat ca instrument de referință pentru verificarea formei originale a unui împrumut în limba română (veche) sau a unui lexem identificat într-un text original în slavonă de pe teritoriul României de astăzi. Există anumite reguli pentru transferul declinărilor și al conjugărilor slave în româna (veche) care pot cauza nesiguranță în procesul de identificare a formei originale. Mai mult decît atît, autorii români ai textelor slavone medievale și din epoca modernă timpurie făceau confuzii cu privire la gen și declinări, în special în cazurile în care genul în slavonă era diferit de cel al echivalentelor românești sau în cazul unor cuvinte cu aceeași terminație (cf. Djamo-Diaconiță, 1968, p. 241-249). Redăm mai jos o serie de comparații între cuvinte din slava veche și cuvinte românești.

- Substantive feminine în română:

- Rom. $-\ddot{a}$ :

* Slav. neutru: mită - SV нтытro, pravilă - SV правияо;

* Slav. masculin: slugă-sv csoyra;

* Slav. feminin: mreajă - sv норжа;

* Slav. feminin, tema în $i$ : poftă/pohtă - noxors.

- Rom. $-e$ :

* Slav. feminin, tema în $i$ : poveste - пов'大cth;

* Slav. feminin, tema în ja: nădejde - Naд̨єдаd.

- Rom. -ie:

* Slav. feminin, tema în $i$ : oblastie - овласть, zavistie - зависть;

* Slav. feminin, tema în ja: utrenie - oүтрьнга, milostenie - нилосттыйи;

* Slav. neutru, tema în jo: spăsenie - c'ъпасєнию.

- Verbe:

- Rom. -ui: a polzui 'a învăţa o lecție' - польsєвати 'a fi util; a avea profit', pers. 1 sg. prezent

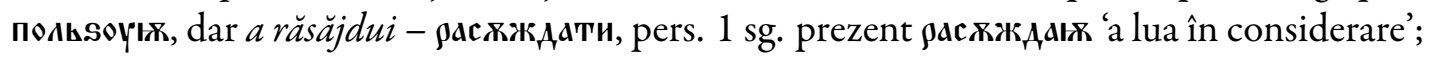

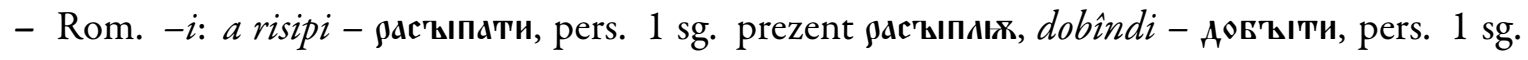

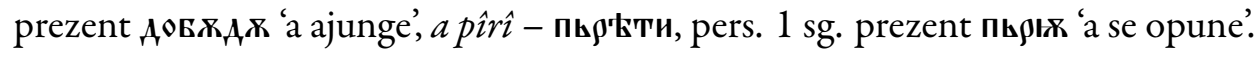

Dicționarul și în special catalogul de fișe pot servi ca punct de referință al valențelor. Astfel, avem posibilitatea de a compara dacă valența atestată într-un text slavon scris de un vorbitor de limbă română corespunde cu valența celor mai vechi texte slavone. Această abordare poate dezvălui impactul sintactic pe care limba română $l$-a avut asupra textelor slavone. Trebuie, fără îndoială, luat în considerare faptul că trăsăturile arealului balcanic sînt comune atît limbii române, cît și limbilor slavice sudice învecinate.

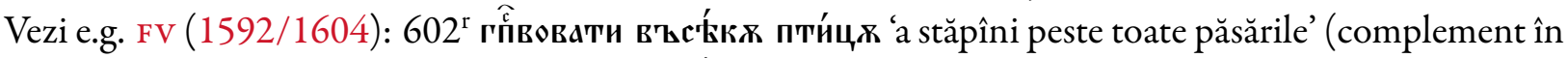
acuzati, OCSD indică dativ), $627^{\vee}$ '̈Блдада́ти на̂̀ пти́цджии 'a stăpîni peste păsări' (complement însoțit de prepoziția Nầ, OCSD indică instrumental fără prepoziție). 


\section{Planuri de viitor}

Finalizarea procesului de digitalizare și parcurgerea primei etape de revizuire a dicționarelor incluse în Gorazd Digital Hub ridică întrebări referitoare la direcțiile în care va continua proiectul. Unul din obiectivele principale pentru viitorul apropiat ar trebui să fie efortul de a asigura consistența bazei de date care include doar extrase parțiale din anumite texte, în special din cele descoperite în 1975 la Mănăstirea Muntele Sinai. Mediul digital face posibilă completarea dicționarului per texte și nu doar per litere, ceea ce reprezintă în mod evident o modalitate mai eficientă (mai multe detalii în Pilát, 2020). Includerea de noi texte poate furniza noi date pentru studiile despre slavona românească; de ex. compararea unităţii lexicale, vezi de exemplu unitatea lexicală чєвє din scrierea glagolitică Vindecarea lui Cosma (Rosenschon, 1994, p. 335), care este forma cea mai apropiată (și cu cea mai veche atestare) de românescul ștevie. În afară de efortul de completare a vocabularului atestat în manuscrisul în slava veche canonică, există și opțiunea de a ne axa pe baza de date a slavonei bisericești cehe.

O altă chestiune care merită discutată în detaliu este eventuala includere a altor baze de date lexicografice digitale cu vocabular slavonic bisericesc (vechi). Ne referim în mod particular la recent elaboratul Dicționar Etimologic al Limbii Slave Vechi (ESJS) bazat pe materialul furnizat d LLP (Pilát, 2020, p. 80) și care reprezintă un instrument de lucru indispensabil pentru cercetătorii specializați în limbi slave, indoeuropene, dar și pentru etimologii români. Teoretic, ne putem gîndi și la integrarea unui dicționar care să se axeze pe vocabularul slavonei românești și al limbii române (vechi). Datorită faptului că fiecare intrare din Gorazd are propriul URL unic, link-urile către intrările singulare din dicționarele Gorazd pot fi pur și simplu adăugate dicționarelor digitale ale diverselor varietăți de limbă slavă sau ale celor de limbă română ${ }^{23}$.

\section{Bibliografie}

Addenda = Hauptová, Z., Konzal, V. \& Pilát, Š. (eds) (2016). Lexicon lingu๔ paleoslovenica - Slovník jazyka staroslovènského, V. Addenda et corrigenda, Academia, Prague.

Berynda, P. (1627). Lexikon" slavenorosskij, i imen" Tl"kovanïe, Lavra Pečerskaja Kievskaja, Kiev.

Bogdan, I. (1922). Cronica lui Manasses. Traducere mediobulgară, Socec \& Co, București.

Bolocan et al. (1981). Dicționarul elementelor romănești din documente slavo-române 1374-1600, Editura ARSR, București.

Cejtlin, R., Večerka, R. \& Bláhová, E. (1994). Staroslavjanskij slovar' (po rukopisjam X-XI vekov), Russkij jazyk, Moscow.

Coresi (1561). Tetraevanghel, Hanăș Beagner, Brașov.

Djamo-Diaconiță, L. (1968). Contribution à l'étude de l'influence roumaine sur la langue des documents slavo-roumains émis par la chancellerie valaque au XVe siècle, în „Revue roumaine de linguistique“, 13 (3), p. 233-252.

Djamo-Diaconiță, L. (1971). Limba documentelor slavo-române emise în Țara Românească în sec. XIV și XV, Editura Academiei, București.

DRH B 1 = Panaitescu, P.P. \& Mioc, D. (1966). Documenta Romani火 Historica, B. Ţara Românească, vol. I, Editura ARSR, București.

ESJS = Havlová, E., Janyšková, I. et al. (1989-2018). Etymologický slovnik jazyka staroslovénského, seš. 1-19, Academia, Prague / Tribun EU, Brno.

FV $=$ [Flower of Virtues] (1592/1604), în Biblioteca Academiei Române, ms. rom. 4620, 1592-1604, ff. 457-627 .

IVGP = Bláhová, E. et al. (2008-2014). Řecko-staroslovénský index - Index verborum greco-paleoslovenicus, fasc. 1-8, vol. I., Euroslavica, Prague.

Knoll, V. (2019a). Gorazd: An Old Church Slavonic Digital Hub, în Miltenova, A., Baranov, V. et al. (eds), Digital and Analytical Approaches to the Written Heritage, Gutenberg, Sofia, p. 114-128.

Knoll, V. (2019b). Lexicografia slavonă și slava veche și intrarea ei în era digitală, în „Studii și cercetări lingvistice”, 70 (1), p. 7487.

Knoll, V. (2021). The "Romanian Slavonic language" and lexicography, în Janyšková, I., Karlíková, H., \& Boček, V. (eds), Old Church Slavonic Heritage in Slavonic and Other Languages, NLN, Prague, p. 307-323.

LLP = Kurz, J. \& Hauptová, Z. (eds) (1958-1997). Lexicon lingux paleslovenica - Slovnik jazyka staroslověnského, fasc. 1-52, 1958-1997, Academia, Prague; vol. I, 1966, vol. II, 1973, vol. III, 1982, vol. IV, 1997.

${ }^{23}$ La fel ca și în Dicționarul Anglo-Normand (dicționar pentru o varietate de franceză veche) care oferă link-uri către $O x f o r d$ English Dictionary, vezi anglo-norman.net. 
Mareš, F. V. (2000). Cyrilometodèjská tradice a slavistika, Torst, Prague.

Mathiesen, R. (1984). The Church Slavonic Language Question: An Overview (IX-XX Centuries), în Picchio R., Goldblatt, H. et al., Aspects of the Slavic Language Question I, Slavica Publishers, New Haven, p. 45-65.

Miklosich, F. (1862-1865). Lexicon paleslovenico-greco-latinum, Guilelmus Braumueller, Vindobonæ.

Moxa, M. (1620). De’ nceputul lumieei... [Cronică], in: Russian State Library, coll. 87, no. 64.

Olteanu, P. et al. (1975). Slava veche și slavona romănească, Editura didactică și pedagogică, București.

Pilát, Š. (2020). Elektronický slovnik jazyka staroslověnského - perspektivy dalš́ho vývoje, în „Bohemica Olomucensia. Linguistica“, p. 74-90.

Pilát, Š et al. (2018). The Gorazd Project: An Old Church Slavonic Digital Hub, Academia, Prague, [online].

Rosenschon, U. (1994). Sechs Seiten medizinischer Rezepte im glagolitischen Psalter $3 / N$ des Sinaiklosters, în „Byzantinoslavica“, LX (2), p. 304-335.

SBR = Ivanova-Mirčeva, Dora et al. (1999). Starobălgarski rečnik, tom 1-2, Valentin Trajanov, Sofia.

ssum = Humec'ka, L. L. et al. (1977-1978). Slovnyk staroukrajins'koji movy XIV-XV st. 1-2, Naukova dumka, Kiev.

Tolstoj, N.N. (1988). Istorija i struktura slavjanskich literaturnych jazykov, Nauka, Moscow. 